\title{
Knowledge and Attitudes toward HPV and the HPV Vaccines in The Bahamas
}

\author{
D Halliday ${ }^{1,2}$, R Butler ${ }^{1,2}$, D Francis ${ }^{1}$, J Thompson ${ }^{2,3}$, M Joseph $^{1}$, CC Ragin ${ }^{2,4}$
}

\begin{abstract}
Objective: High-risk types of human papillomavirus (HPV) are a necessary, albeit not sufficient, cause for cervical cancer development. In The Bahamas, cervical cancer is one of the leading causes of cancer despite screening and educational efforts. As a vaccine programme is being considered, awareness of HPV-related conditions and its vaccine needs to be measured.

Methods: This study design was cross-sectional and carried out at three clinical sites and one community in Nassau, Bahamas. All participants were over the age of 18 years and were invited to answer a (self-administered) questionnaire regarding knowledge and attitudes toward HPV and its vaccines.

Results: Of 399 participants, $75 \%$ were female and $23 \%$ male. About $41 \%$ had a high school education and $55.4 \%$ had some tertiary college education. Forty-six per cent had heard of HPV and 35\% heard of the vaccine. The mean number of correct answers about HPV was $2.93 \pm 3.17$ of 10 questions, while for the vaccine, it was $1.37 \pm 1.58$ of five questions. Multivariable logistic regression indicated that some college education was associated with more HPV and HPV vaccine knowledge. Seventy-three per cent needed reassurance of the vaccine's safety and efficacy. Sixty-five per cent would vaccinate their daughters and $68 \%$ would vaccinate their sons if the vaccine was safe and effective.

Conclusion: More public education is needed to increase awareness of cervical cancer and HPVrelated diseases. Reassurance with respect to vaccine safety and efficacy also needs to be addressed. Since the majority would vaccinate their children, there is the potential for a national vaccination programme to succeed.
\end{abstract}

Keywords: Attitudes, Caribbean, human papillomavirus (HPV), knowledge, The Bahamas, vaccine

\section{Conocimientos y Actitudes hacia el VPH y las Vacunas contra VPH en Las Bahamas} D Halliday ${ }^{1,2}$, R Butler ${ }^{1,2}$, D Francis ${ }^{1}$, J Thompson ${ }^{2,3}$, M Joseph ${ }^{1}$, CC Ragin ${ }^{2,4}$

\begin{abstract}
RESUMEN
Objetivo: Los tipos de alto riesgo del virus del papiloma humano (VPH) son una medida necesaria, aunque no constituyen causa suficiente para el desarrollo de cáncer cervical. En las Bahamas, el cáncer de cuello uterino es una de las principales causas de cáncer a pesar de los esfuerzos realizados en términos de pesquizaje y educación. En un momento en que se está considerando la posibilidad de un programa de vacunación, es necesario evaluar el nivel de conciencia con respecto a las condiciones relacionadas con el VPH y su vacuna.

Métodos: Se trata de un estudio con un diseño transversal, llevado a cabo en tres clínicas y en una comunidad, en Nassau, Bahamas. Todos los participantes eran mayores de 18 años y fueron invitados a responder un cuestionario autoadministrado sobre conocimientos y actitudes hacia el VPH y sus vacunas.

Resultados: De 399 participantes, el 75\% eran hembras y el 23\% eran varones. Aproximadamente el $41 \%$ tenía educación secundaria y el 55,4\% tenía algún nivel de educación terciaria. El cuarenta y seis por ciento había oído del VPH, y el 35\% había oído hablar de la vacuna. El número promedio de respuestas correctas sobre el VPH fue $2.93 \pm 3.17$ de 10 preguntas, mientras que para la vacuna, fue
\end{abstract}

From: ${ }^{1}$ Department of Obstetrics and Gynaecology, Princess Margaret Hospital, Nassau, Bahamas, ${ }^{2}$ African Caribbean Cancer Consortium (http://ac3online.org), ${ }^{3}$ Department of Family Medicine, Princess Margaret Hospital, Nassau, Bahamas and ${ }^{4}$ Cancer Prevention and Control Programme, Fox Chase Cancer Centre, Philadelphia, PA, USA.
Correspondence: Dr D Halliday, Department of Obstetrics and Gynaecology, Princess Margaret Hospital, Nassau, Bahamas. E-mail: darron.halliday @gmail.com 
$1.37 \pm 1.58$ de cinco preguntas. La regresión logística multivariable indicó cierta asociación de la educación universitaria con más conocimientos sobre el VPH y la vacuna del VPH. Setenta y tres por ciento necesitaban garantías de seguridad y eficacia en relación con la vacuna. El sesenta y cinco por ciento vacunaría a sus hijas, y el 68\% vacunaria a sus hijos varones, si la vacuna fuese segura y efectiva.

Conclusión: Se requiere más educación pública para aumentar la conciencia sobre el cáncer de cuello uterino y las enfermedades relacionadas con el VPH. Asimismo hay que abordar el problema de las garantías respecto a la eficacia y seguridad de la vacuna. Puesto que la mayoría vacunaría a sus hijos e hijas, existe la posibilidad de que un programa nacional de vacunación tenga éxito.

Palabras claves: Caribe, virus del papiloma humano (VPH), actitudes, conocimientos, las Bahamas, vacuna

West Indian Med J 2013; 62 (8): 732

\section{INTRODUCTION}

Papillomaviruses are epitheliotrophic DNA viruses, which predominantly infect the skin and mucous membranes (1). Human papillomavirus 6 and 11 are associated with $90 \%$ of anogenital warts while HPV 16 and 18 are associated with $70 \%$ of high-grade cervical dysplasia and cervical cancer (2). Other high-risk subtypes associated with cervical cancer include HPV 31, 33, 35, 39, 45, 51, 52, 56, 58, 59 and 66 (2).

About $10 \%$ of women in the general population are estimated to harbour cervical HPV infection at any given time (3). Approximately 75 to $80 \%$ of sexually active adults will acquire a genital tract HPV infection before the age of 50 years (4).

The main burden of HPV-related disease is due to cervical cancer, which is the second most common cancer in women worldwide with 500000 cases diagnosed annually and 270000 deaths $(2,3)$. In Latin America and the Caribbean, it is the leading cause of years of life lost from cancer (5) with approximately 33000 annual deaths $(3,6)$. This translates into an economic loss in productivity of US\$3.3 billion per year (6). In The Bahamas, the incidence of cervical cancer is 16.7/100 000 (3). Developed countries such as the United Kingdom (UK) have successfully reduced death from cervical cancer through effective screening programmes (7).

Much of the prior work in the Caribbean focussed on Pap smear knowledge and attitudes (8-10). While there was some knowledge of the Pap smear and its purpose, high-risk sexual behaviour was not uncommon and there were few who adhered to the screening guidelines. Education and religion influenced these factors. With respect to HPV and HPV vaccine knowledge, prior data from Central and South America suggest that while knowledge is limited, acceptance is high after education (11-13). In Grenada, among college students, the purpose of the Pap smear was known but the association between cervical cancer and HPV was recognized only in about $54 \%$ of males and $64 \%$ of females (14).

Pap smear coverage in The Bahamas has remained about 10 to $15 \%$ over the past decade, although there are government clinics close to each community which offer this service. In addition, The Cancer Society of The Bahamas carries out annual Pap smear campaigns, during which healthcare providers educate the community about cervical cancer or other relevant health topics. Despite these efforts, the number of Pap smears processed annually at The Princess Margaret Hospital (the main tertiary medical institution in The Bahamas) has decreased.

In 2006, the US Food and Drug Administration (FDA) approved the quadrivalent vaccine for females, protecting against HPV 6, 11, 16 and 18, (15) and in 2009, the bivalent HPV vaccine which protects against HPV 16 and 18 (16). In 2009 , the US FDA licensed the use of the quadrivalent vaccine for 9-26-year old males against genital warts caused by HPV 6 and 11 (15). While there was considerable media attention in The Bahamas, the uptake of the vaccine has been mainly in the private sector.

The trend of decreasing Pap smear rates in The Bahamas prompted us to measure knowledge of HPV, cervical cancer and other HPV-related conditions and also to determine knowledge of the HPV vaccine.

\section{SUBJECTS AND METHODS}

The survey was conducted from December 2008 to March 2010, once Institutional Review Board approval was obtained. Both males and females over the age of 18 years were invited to participate. Participants were recruited from the Family Medicine Clinic at the Princess Margaret Hospital, two private clinics not affiliated with the government hospital and one community site, using a convenience sampling technique. At the community site, passers-by were stopped and asked if they were willing to participate in the study. The original English questionnaire was formally translated into Haitian Creole by the Haitian Embassy in The Bahamas in order to accommodate Creole speaking participants. Those who were not able to read or write well had assistance in completing the questionnaire. Participants were not required to give their name or any contact information.

The questionnaire used in this study was developed and published in an earlier study (17). The questions pertained to age, race, gender, place of birth, religion, household income, level of education, health insurance status, parental status and number of children. Participants also answered questions 
pertaining to their knowledge of HPV and the safety, efficacy and impact of the HPV vaccine. Willingness to have the vaccine or have their children vaccinated was also explored. Data were analysed using SPSS 17.0 for Windows (SPSS Inc., Chicago, IL, USA). The significance level was set at $p<0.05$. Descriptive statistics were generated for demographic and knowledge variables. Fisher's exact test was used to determine statistically significant differences between proportions; differences in continuous variables were assessed using two-sample $t$-tests. Multivariable logistic regression analyses were used to identify factors associated with HPV knowledge, and vaccine knowledge.

\section{RESULTS}

There were a total of 620 surveys issued with 399 completing the survey (response rate 64.6\%). Of these, 298 (75\%) were female, $94(23 \%)$ were male and seven $(2 \%)$ did not give their gender. The majority of the participants, $342(85.7 \%)$, were of African descent, six $(1.5 \%)$ were Caucasian, 31 (7.8\%) other, and 20 (5\%) did not respond (Table 1). With respect to country of birth, $306(76.7 \%)$ of the participants were born in The Bahamas. The largest group of persons not born in The Bahamas was from Haiti $[\mathrm{n}=58](14.5 \%)$. There were 13 (3.3\%) who were born in Jamaica and 13 $(3.3 \%)$ in other countries. For education, $163(40.9 \%)$ had some high school education or less, while 221 (55.4\%) had at least some tertiary education. The majority, $282(70.7 \%)$, were sexually active. Of the 302 participants who indicated their annual household income levels, 50.7\% had an income of $\$ 25000$ or less while $49.3 \%$ had an income greater than $\$ 25000$. Forty-eight per cent had no health insurance, however, $46 \%$ had some health insurance. Eighty-seven per cent of the partici-pants belonged to the Christian religion and there were $7.5 \%$ of other faiths. There were $5.5 \%$ nonresponders.

Table 1: Demographics of the survey participants

\begin{tabular}{|c|c|c|c|c|c|}
\hline Variable & Bahamas & Haiti & Other & NR & All \\
\hline \multicolumn{6}{|l|}{ Gender } \\
\hline Female & $243(79.4 \%)$ & $29(50.0 \%)$ & $17(65.4 \%)$ & 0 & $289(74.7 \%)$ \\
\hline Male & $57(18.6 \%)$ & $28(48.3 \%)$ & $9(34.6 \%)$ & $9(100 \%)$ & $94(23.6 \%)$ \\
\hline NR & $6(2.0 \%$ & $1(1.7 \%)$ & $0(0.0 \%)$ & 0 & $7(1.8 \%)$ \\
\hline \multicolumn{6}{|l|}{ Age (Years) } \\
\hline$\leq 45$ & $227(74.2 \%)$ & $38(65.5 \%)$ & $18(69.2 \%)$ & $6(66.7 \%)$ & $289(72.4 \%)$ \\
\hline$\geq 46$ & $73(23.9 \%)$ & $19(32.8 \%)$ & $8(30.8 \%)$ & $1(11.1 \%)$ & $101(25.3 \%)$ \\
\hline NR & $6(2.0 \%)$ & $1(1.7 \%)$ & $0(0 \%)$ & $2(22.2 \%)$ & $9(2.3 \%)$ \\
\hline \multicolumn{6}{|l|}{ Race } \\
\hline African descent & $268(87.6 \%)$ & $55(94.8 \%)$ & $16(61.5 \%)$ & $3(33.3 \%)$ & $342(85.7 \%)$ \\
\hline Other & $23(7.5 \%)$ & $2(3.4 \%)$ & $9(34.6 \%)$ & $3(33.3 \%)$ & $37(9.3 \%)$ \\
\hline NR & $15(4.9 \%)$ & $1(1.7 \%)$ & $1(3.8 \%)$ & $20(5.0 \%)$ & \\
\hline \multicolumn{6}{|l|}{ Education } \\
\hline$\leq$ High school education & $104(34.0 \%)$ & $50(86.2 \%)$ & $8(30.8 \%)$ & $1(11.1 \%)$ & $163(40.9 \%)$ \\
\hline$\geq$ Some college education & $195(63.7 \%)$ & $6(10.3)$ & $18(69.2 \%)$ & $2(22.2 \%)$ & $221(55.4 \%)$ \\
\hline $\mathrm{NR}$ & $7(2.3 \%)$ & $2(3.4 \%)$ & $0(0 \%)$ & $6(66.7 \%)$ & $15(3.8 \%)$ \\
\hline \multicolumn{6}{|l|}{ House hold income } \\
\hline$<25000 /$ year & $100(32.7 \%)$ & $44(75.9 \%)$ & $7(26.9 \%)$ & $2(22.2 \%)$ & $153(38.3 \%)$ \\
\hline$>25000 /$ year & $120(39.2 \%)$ & $12(20.7 \%)$ & $1(6.61 .5 \%)$ & $1(11.1 \%)$ & $149(37.3 \%)$ \\
\hline NR & $(86(28.1 \%)$ & $2(3.4 \%)$ & $3(11.5 \%)$ & $6(66.7 \%)$ & $97(24.3 \%)$ \\
\hline \multicolumn{6}{|l|}{ Sexually active } \\
\hline No & $82(26.8 \%)$ & $2(3.4 \%)$ & $3(11.1 \%)$ & $1(11.1 \%)$ & $88(22.1 \%)$ \\
\hline Yes & $204(66.7)$ & $53(91.4 \%)$ & $23(88.5 \%)$ & $2(22.2 \%)$ & $282(70.7 \%)$ \\
\hline NR & $20(6.5 \%)$ & $(3(5.2 \%)$ & $0(0 \%)$ & $6(66.7 \%)$ & $29(7.3 \%)$ \\
\hline \multicolumn{6}{|l|}{ Religion } \\
\hline Christian & $272(88.9 \%)$ & $53(91.4 \%)$ & $18(69.2 \%)$ & $4(44.4 \%)$ & $347(87.0 \%)$ \\
\hline Other & $17(5.6 \%)$ & $4(6.9 \%)$ & $8(30.8 \%)$ & $1(11.1 \%)$ & $30(7.5 \%)$ \\
\hline NR & $17(5.6 \%)$ & $1(1.7 \%)$ & $0(0 \%)$ & $4(44.4 \%)$ & $22(5.5 \%)$ \\
\hline \multicolumn{6}{|l|}{ Health insurance } \\
\hline No & $126(41.2 \%)$ & $53(91.4 \%)$ & $11(42.3 \%)$ & $3(33.3 \%)$ & $193(48.4 \%)$ \\
\hline Yes & $163(53.3 \%)$ & $3(5.2 \%)$ & $14(53.8 \%)$ & $2(22.2 \%)$ & $182(45.6 \%)$ \\
\hline NR & $17(5.6 \%)$ & $2(3.4 \%)$ & $1(3.8 \%)$ & $4(44.4 \%)$ & $24(6.0 \%)$ \\
\hline Total $^{*}$ & $306(76.7 \%)$ & $58(14.5 \%)$ & $26(6.5 \%)$ & $9(2.26 \%)$ & 399 (100) \\
\hline
\end{tabular}

Note: Percentages are of column totals (except where ${ }^{*}$ shows percentage participants according to country of birth)

$\mathrm{NR}=$ no response/missing data 
When Bahamian and Haitian born respondents were compared, significantly more Haitian born participants were in the low household annual income group and received no more than a high school education $(p=<0.001$ in both instances). There were more males in the Haitian born group ( $p=<0.001$ ), but there were no significant differences between the groups with respect to age, religion and race (Table 1).

\section{HPV knowledge}

The study participants were asked whether or not they had heard of HPV and then asked to complete ten additional questions regarding HPV knowledge. Forty-six per cent of the participants had heard of HPV, 48\% had not and 6\% did not respond to the question. Multivariable logistic regression analyses showed that when Bahamian and Haitian born participants were compared, persons with some college education and persons who were born in The Bahamas were more likely to have heard of HPV (Table 4).

Table 2 shows the number of correct answers for all participants. The mean knowledge score for the ten ques-

Table 2: Portion of participants able to answer question regarding human papillomavirus (HPV) correctly

\begin{tabular}{|c|c|c|}
\hline $\begin{array}{l}\text { Numb } \\
\text { with }\end{array}$ & $\begin{array}{l}\text { of participants } \\
\text { correct answers }\end{array}$ & Per cent \\
\hline $\begin{array}{l}\text { HPV is not sexually transmitted } \\
\text { (false) }\end{array}$ & 104 & 26.1 \\
\hline $\begin{array}{l}\text { HPV infection is relatively } \\
\text { uncommon (false) }\end{array}$ & 136 & 34.1 \\
\hline HPV causes cervical cancer (true) & 171 & 42.9 \\
\hline $\begin{array}{l}\text { Who can become infected with } \\
\text { HPV? (Both men and women) }\end{array}$ & 116 & 26.6 \\
\hline $\begin{array}{l}\text { Both men and women can have } \\
\text { cervical cancer (false) }\end{array}$ & 217 & 54.4 \\
\hline $\begin{array}{l}\text { The incidence of HPV in women } \\
\text { is highest among women in their } \\
20 \text { s and } 30 \text { s (true) }\end{array}$ & 119 & 29.8 \\
\hline $\begin{array}{l}\text { Most people with genital HPV } \\
\text { infections are symptomatic (false) }\end{array}$ & 81 & 20.3 \\
\hline HPV causes genital warts (true) & 106 & 26.6 \\
\hline $\begin{array}{l}\text { Genital warts are caused by the } \\
\text { same HPV types that cause } \\
\text { cervical cancer (false) }\end{array}$ & 38 & 9.5 \\
\hline There is a cure for HPV infection (false) & 81 & 20.3 \\
\hline
\end{tabular}

tions asked was $2.93 \pm 3.17$. For the whole group, $7 \%$ thought that both men and women could have cervical cancer. The means scores for persons with high school education versus persons with some college education were 1.5 \pm 2.2 and $4.1 \pm 3.3$, respectively, $p \leq 0.001$. When the mean scores of participants born in The Bahamas were compared to Haitian born participants, the scores were $3.14 \pm 3.13$ and $0.84 \pm 1.62$, respectively, $p \leq 0.001$. Multivariable logistic regression analyses indicated that some college education versus high school or less and income greater than 25000 versus less were the factors associated with a good knowledge score of seven or more correct questions out of ten. Religion, gender, age, and birth place (Haiti versus Bahamas) were not significant factors.

\section{Knowledge and perception of the HPV vaccine}

When asked whether they had heard of the HPV vaccine, 141 (35\%) had heard of the vaccine, 157 (40\%) had not, $44(11 \%)$ indicated that they were unsure and there were 57 (14\%) nonresponders. Multivariable logistic regression analyses indicated that some college education $v s$ high school or less, and country of birth (Bahamas vs Haiti) were the significant factors which had influence on whether the participant heard of the HPV vaccine. Income, gender and age were not significant factors (Table 4). Of those that heard of HPV, 46\% learnt about it from an advertisement, 22\% heard about it at school, $22 \%$ heard about it from a healthcare professional, $5 \%$ on the news, $1 \%$ from a friend and 5\% from another source.

Table 3 shows the number of correct answers for all participants with respect to HPV vaccine knowledge. Of five

Table 3: Portion of participants able to answer question regarding human papillomavirus (HPV) vaccine correctly

\begin{tabular}{lcc}
\hline Question & \multicolumn{1}{c}{$\begin{array}{c}\text { Number of } \\
\text { participants with } \\
\text { correct answers }\end{array}$} & Per cent \\
\hline $\begin{array}{l}\text { The HPV vaccine is approved for } \\
\text { individuals who have never been } \\
\text { infected with HPV (true) }\end{array}$ & 28.3 \\
$\begin{array}{l}\text { Who is eligible for the HPV vaccine? } \\
\text { (Both males and females) }\end{array}$ & 63 & 15.8 \\
$\begin{array}{l}\text { For which age group is the HPV } \\
\text { vaccine recommended? ( Ages 9-26 years) }\end{array}$ & 115 & 28.8 \\
$\begin{array}{l}\text { The current FDA approved HPV vaccine } \\
\text { protects against genital warts and most } \\
\text { cervical cancer (true) }\end{array}$ & 93 & 23.3 \\
$\begin{array}{l}\text { Once vaccinated women no longer } \\
\text { have to be screened (annual Pap smears) } \\
\text { for cervical cancer (false) }\end{array}$ & 163 & 40.9 \\
\hline
\end{tabular}

questions, the mean knowledge score for all the participants was $1.37 \pm 1.58$. The mean scores for persons with high school education versus persons with some college education were $0.7 \pm 1.3$ and $1.9 \pm 1.6$, respectively, $p<0.001$. When Bahamian born participants were compared with those born in Haiti, the scores were $1.45 \pm 1.56$ and $0.55 \pm 1.11$, respectively $(p<0.001)$. Multivariable logistic regression 
analyses showed some college education versus high school or less was the only significant factor which influenced whether a participant had a good knowledge score of four or more correct answers. Income, gender, age and birth place (Haiti versus Bahamas) were not of significance (Table 4). and HPV vaccines is very limited (11-14). In spite of this, however, the vaccine is acceptable once there is understanding of its purpose (11-13). In Honduras, 632 mothers were interviewed and it was noted that only $13 \%$ had heard of HPV vaccination and knowledge of associated conditions

Table 4: Multivariable logistic regression to determine the factors associated with good human papillomavirus (HPV) and HPV vaccine knowledge

\begin{tabular}{|c|c|c|c|c|c|c|c|c|}
\hline \multirow[t]{2}{*}{ Variables } & \multirow{2}{*}{\multicolumn{2}{|c|}{$\begin{array}{r}\text { Heard of HPV } \\
95 \%\end{array}$}} & \multicolumn{2}{|c|}{$\begin{array}{l}\text { Good knowledge } \\
\text { of HPV } \\
\text { (7/10 questions } \\
\text { correct) }\end{array}$} & \multicolumn{2}{|c|}{$\begin{array}{l}\text { Heard of HPV } \\
\text { vaccine }\end{array}$} & \multicolumn{2}{|c|}{$\begin{array}{l}\text { Good knowledge } \\
\text { of HPV vaccine } \\
\text { ( } 4 / 5 \text { questions } \\
\text { correct) }\end{array}$} \\
\hline & & & & $\begin{array}{c}95 \% \\
\text { CI }\end{array}$ & & $\begin{array}{c}95 \% \\
\text { CI }\end{array}$ & & $\begin{array}{c}95 \% \\
\text { CI }\end{array}$ \\
\hline $\begin{array}{l}\text { Education } \\
\text { Some college } v s \text { less }\end{array}$ & $5.55^{*}$ & $2.79,11.02$ & $3.83 *$ & $1.37,10.71$ & $5.26^{*}$ & $2.45,11.30$ & $3.18^{*}$ & $1.28,7.93$ \\
\hline $\begin{array}{l}\text { Income } \\
>25000 v s \leq 25000\end{array}$ & $2.04 *$ & $1.06,3.92$ & $3.15^{*}$ & $1.41,7.00$ & 1.18 & $0.57,2.43$ & 1.75 & $0.84,3.63$ \\
\hline $\begin{array}{l}\text { Gender } \\
\text { female } v s \text { male }\end{array}$ & 2.33 & $1.06,5.11$ & 1.07 & $0.44,2.64$ & 1.49 & $0.66,3.41$ & 2.04 & $0.92,4.52$ \\
\hline $\begin{array}{l}\text { Age (years) } \\
<46 v s \geq 46\end{array}$ & 1.14 & $0.54,2.43$ & 1.39 & $0.56,3.42$ & 1.83 & $0.82,4.08$ & 1.11 & $0.49,2.52$ \\
\hline $\begin{array}{l}\text { Race } \\
\text { Black vs other }\end{array}$ & 1.16 & $0.30,4.55$ & 2.06 & $0.54,7.88$ & 3.52 & $0.91,13.64$ & 1.76 & $0.35,8.75$ \\
\hline $\begin{array}{l}\text { Religion } \\
\text { Christian } v s \text { other }\end{array}$ & 2.75 & $0.52,14.57$ & 1.47 & $0.39,5.61$ & 1.65 & $0.36,7.57$ & 3.94 & $0.49,31.86$ \\
\hline $\begin{array}{l}\text { Birthplace } \\
\text { Bahamas vs Haiti }\end{array}$ & $9.32 *$ & $2.51,34.54$ & 0 & $0.00,0.00$ & $8.87^{*}$ & $2.39,32.93$ & 2.29 & $0.58,9.01$ \\
\hline
\end{tabular}

*Statistically significant result

With respect to vaccine efficacy, $73.3 \%$ agreed that there was still need for reassurance, $3.3 \%$ felt it was effective and the remainder did not reply. The proportions were the same with respect to reassurance of vaccine safely. Of those who had daughters $(n=174), 65 \%$ would vaccinate their daughters, $3 \%$ would not and $32 \%$ were unsure if they would. Similarly, of those who had sons $(n=155), 68 \%$ would vaccinate them, $2 \%$ would not and $30 \%$ were unsure.

Of those that would not vaccinate their daughters $(\mathrm{n}=$ $29)$ their main concerns were safety (38\%), while $7 \%$ had general concerns as this was a new vaccine. Twenty-one per cent felt the vaccine was not needed as their children were adults. Only $3 \%$ felt that the vaccine promoted risky sexual behaviour. Of those that would not vaccinate their sons $(\mathrm{n}=$ 30 ), the main concerns were also safety (33\%) while $23 \%$ had general concerns as this was a new vaccine, and $20 \%$ felt the vaccine was not needed since their children were adult. Only $10 \%$ felt that the vaccine promoted risky sexual behaviour.

\section{DISCUSSION}

The results show that in The Bahamas, as in other regions in Latin America, knowledge of HPV, HPV-related conditions was limited. After education, 91\% would accept HPV vaccination for a nine-year old daughter (11). Also in Honduras, a survey of 100 fathers revealed that $22 \%$ heard of HPV and $17 \%$ heard of the vaccine. After receiving HPV-related information, $100 \%$ of fathers intended to accept HPV vaccination for their sons and 94\% intended to accept HPV vaccination for their daughters (12). In Brazil, a hospital survey of 301 primiparous women showed that $37 \%$ heard about HPV. Only 19\% and 7\%, respectively, knew that HPV is a sexually transmitted infection (STI) and that it can cause cervical cancer. Seventy-four per cent of interviewees mentioned the preventive character of vaccines and all participants affirmed that they would accept HPV vaccination after delivery (13). In our survey, $73.3 \%$ felt that there needs to be reassurance of vaccine efficacy and safety. Nevertheless, 65\% who had daughters and 68\% who had sons would have them vaccinated. Further study in our population is needed to determine how educational interventions will improve the acceptance of the vaccine.

Both the quadrivalent and bivalent vaccines have been shown to be safe and effective. The FUTURE I study was a phase III placebo control trial with 5455 women between the ages of 16 and 24 years. The efficacy against HPV 6, 11, 16 
and 18 was $73 \%(95 \%$ CI 58,83$)$ when all grades of external anogenital or vaginal lesions were combined. The analysis included women with prevalent infections. The quadrivalent vaccine was found to be $100 \%$ effective in preventing type specific HPV-related warts disease in women who were HPV naïve and also in preventing cervical intraepithelial neoplasia (CIN) and adenocarcinoma in situ [AIS] (18). The vaccine was well tolerated in this trial. About $10 \%$ experienced a local reaction such as pain, pruritus and/or swelling and 3\% were more likely to experience fever (18). The bivalent vaccine was evaluated in the PATRICIA study, a phase III, multi-centre, double blind placebo control trial, with more than 18000 women. The ages were $15-25$ years. In the total vaccine cohort (TVC) for persons who were HPV naïve, vaccine efficacy irrespective of HPV DNA in the lesion was about $70 \%$ against CIN2 or worse lesions (19). Vaccine efficacy against CIN3+ associated with HPV-16/18 was $100 \%(95 \%$ CI $85.5,100)$ in the TVC-naïve (20). This knowledge needs to be disseminated to the communities in The Bahamas to allay fears and misconceptions.

Improving knowledge and understanding could improve the acceptance of the HPV vaccine and will have an important role to play as The Bahamas develops an HPV vaccination programme. In our series, some college education seems to be associated with better knowledge. Educational intervention focussing on basic HPV and HPV-vaccine knowledge, safety and efficacy could be done in schools. Health education classes have been found to be a major source of health information about sexually transmitted infections [STIs] (21). In pre-education and post-education surveys of adolescent girls 12-19 years, the intention to vaccinate rose from $35 \%$ to $69 \%$ (22). In Honduras, mothers and fathers would accept HPV vaccination for their children after a brief education programme although there was little awareness initially $(11,12)$.

Education through schools, health professionals and advertising campaigns could be effective, since $90 \%$ of those that knew of the HPV vaccine in our study, heard via one of these means. Education with respect to the importance of screening needs to be continued. A social marketing campaign initiated by 13 North Carolina counties in the United States of America (USA) included promotional posters, brochures, website, news releases and doctors' recommendation, that were placed in doctors' offices and retail outlets. The campaign successfully targeted mothers of 11-12-year olds and the healthcare providers who serve them, to increase vaccine uptake (23). Extensive marketing campaigns in Canada, the USA and Germany have been effective, although content may have been considered controversial (24). A systematic review of parental surveys about HPV and/or child HPV vaccination showed the percentage of parents who heard about HPV rose over time (from $60 \%$ in 2005 to $93 \%$ in 2009), as did their appreciation for the HPV infection and cervical cancer link [from 70\% in 2003 to $91 \%$ in 2011] (25) which may have been the result of the marketing campaigns. Both HPV vaccines have been placed on the World Health Organization (WHO) pre-approval list of vaccines and would enable developing countries such as The Bahamas to procure the vaccine at a greatly reduced rate (26). A press release from the Ministry of Health has indicated that the needed protocols are being developed for the implementation of a HPV vaccine programme in The Bahamas (27). In order for the public health planners to determine the scope of education as well as other interventions required to ensure acceptance and uptake of the HPV vaccine, knowledge and attitudes toward HPV, HPV-related disease and the HPV vaccines needed to be determined (6).

The participants were persons who resided in New Providence which is the main urban region and this serves as a limitation. The Bahamas is made up of 700 islands and keys, thus the overall findings in this study population may not be applicable to all of The Bahamas. Since Nassau is home to The College of The Bahamas as well as The Bahamas campus of the University of the West Indies, it is not surprising that the portion of college educated persons in this survey was $55 \%$. It is unlikely that data from other regions of The Bahamas would show better knowledge since the portion of college educated persons would be less and college education was associated with good knowledge.

In summary, more public education is needed to increase awareness of cervical cancer and HPV-related diseases. Reassurance with respect to vaccine safety and efficacy also needs to be addressed. Since approximately $65 \%$ of the participants who had children would vaccinate their sons and daughters, there is the potential for national vaccination programmes to succeed, as high herd immunity may be achieved.

\section{ACKNOWLEDGEMENTS}

The authors would like to thank the Department of Obstetrics and Gynaecology, Princess Margaret Hospital, Nassau, for their support; Dr Yvette Thimothee, Princess Margaret Hospital and the Haitian Embassy, Nassau, Bahamas, for translating the questionnaire into Haitian Creole; Professor Prafull Ghatage, Programme Director Gynaecologic Oncology Fellowship Programme, Tom Baker Cancer Centre and Foothills Medical Centre, University of Calgary, Calgary $\mathrm{AB}$, for the review of this paper and Dr Yarrow McConnell, Surgical Oncology Fellow, Tom Baker Cancer Centre and Foothills Medical Centre, University of Calgary, Calgary AB, for the statistical advice.

\section{Authors' note}

We declare that we do not have stocks, bonds or financial interest in the aforementioned companies or trademarked products mentioned, neither have we received any incentives nor any form of compensation from them for this work. We do not have any conflicts of interest. 


\section{REFERENCES}

1. Wright C, Kurman RAF. Precancerous lesions of the cervix. In: Kurman R, ed. Blaustein's Pathology of the Female Genital Tract. New York: Springer; 2002: 253-324.

2. Cutts FT, Franceschi S, Goldie S, Castellsague X, de Sanjose S, Garnett $\mathrm{G}$ et al. Human papillomavirus and HPV vaccines: a review. Bull World Health Organ 2007; 85: 719-26.

3. Castellsagué X, de Sanjosé S, Aguado T, Louie KS, Bruni L, Muñoz J et al, eds. HPV and cervical cancer in the world 2007 report: world. Vaccine 2007; 25 (Suppl 3): C1-C26.

4. Gerberding J. Report to Congress: prevention of genital human papillomavirus infection. Centers for Disease Control and Prevention; 2004 [cited 2012 Aug 14]; Available from: http://www.cdc.gov/ std/HPV/2004HPV\%20report.pdf

5. Yang BH, Bray FI, Parkin DM, Sellors JW, Zhang Z-F. Cervical cancer as a priority for prevention in different world regions: an evaluation using years of life lost. Int J Cancer 2004; 109: 418-24.

6. Luciani S, Andrus JK. A Pan American Health Organization strategy for cervical cancer prevention and control in Latin America and the Caribbean. Reproductive Health Matters 2008; 16: 59-66.

7. Quinn M, Babb P, Jones J, Allen E. Effect of screening on incidence of and mortality from cancer of cervix in England: evaluation based on routinely collected statistics. BMJ 1999; 318: $904-8$.

8. Abrahams MA, Rattray CA, Mullings AM, McCaw Binns AM, Douglas KG. Knowledge, attitudes and practices of women regarding Pap smears. West Indian Med J 1997; 46 (Suppl 2): 30.

9. Sterling VL. Knowledge, attitudes and practices of women ages 25-54 years in Hanover with regards to cancer of the cervix [MPh]. Kingston: UWI; 2001.

10. Singh H. A study of health risk behaviour and social factors of women between ages 25-59 years in Trinidad [Masters]. St Augustine: UWI; 2005.

11. Perkins RB, Langrish SM, Cotton DJ, Simon CJ. Maternal support for human papillomavirus vaccination in Honduras. J Womens Health (Larchmt) 2011; 20: 85-90.

12. Perkins RB, Mehta PK, Langrish SM. Fathers' intentions to accept human papillomavirus vaccination for sons and daughters: exploratory findings from rural Honduras. Int J Public Health 2012; 57: 143-8.

13. Rama CH, Villa LL, Pagliusi S, Andreoli MA, Costa MC, Aoki AL et al. Awareness and knowledge of HPV, cervical cancer, and vaccines in young women after first delivery in Sao Paulo, Brazil - a crosssectional study. BMC Womens Health 2010; 10: 35.

14. Perrotte N, Gomez A, Mason G, Stroup D. An assessment of knowledge, attitudes and behaviour regarding the human papillomavirus. West Indian Med J 2012; 61: 58-63.

15. US Food and Drug Administration. Vaccines, blood and biologics. Gardasil. 2011 [updated 2011 Oct 25, cited 2012 Aug 17]; Available from: http://www.fda.gov/BiologicsBloodVaccines/Vaccines/ Approved Products/UCM094042
16. US Food and Drug administration. Vaccines, blood and biologics. Cervarix. 2012 [updated 2012 Jul 19, cited 2012 Aug 17]; Available from: http://www.fda.gov/biologicsbloodvaccines/vaccines/approved products/ucm $186957 . \mathrm{htm}$

17. Ragin CC, Edwards RP, Jones J, Thurman NE, Hagan KL, Jones EA et al. Knowledge about human papillomavirus and the HPV vaccine - a survey of the general population. Infect Agent Cancer 2009; 4 (Suppl 1): $S 10$.

18. Garland SM, Hernandez-Avila M, Wheeler CM, Perez G, Harper DM, Leodolter $\mathrm{S}$ et al. Quadrivalent vaccine against human papillomavirus to prevent anogenital diseases. N Engl J Med 2007; 10; 356: 1928-43.

19. Paavonen J, Naud P, Salmeron J, Wheeler CM, Chow SN, Apter D et al. Efficacy of human papillomavirus (HPV)-16/18 AS04-adjuvanted vaccine against cervical infection and precancer caused by oncogenic HPV types (PATRICIA): final analysis of a double-blind, randomised study in young women. Lancet 2009; 25: 301-14.

20. Lehtinen M, Paavonen J, Wheeler CM, Jaisamrarn U, Garland SM, Castellsagué X et al. Overall efficacy of HPV-16/18 AS04-adjuvanted vaccine against grade 3 or greater cervical intraepithelial neoplasia: 4year end-of-study analysis of the randomised, double-blind PATRICIA trial. Lancet Oncol 2012; 13: 89-99.

21. Baer H, Allen S, Braun L. Knowledge of human papillomavirus infection among young adult men and women: implications for health education and research. J Community Health 2000; 25: 67-78.

22. Chan SS, Yan Ng BH, Lo WK, Cheung TH, Hung Chung TK. Adolescent girls' attitudes on human papillomavirus vaccination. J Pediatr Adolesc Gynecol 2009; 22: 85-90.

23. Cates JR, Shafer A, Diehl SJ, Deal AM. Evaluating a county-sponsored social marketing campaign to increase mothers' initiation of HPV vaccine for their pre-teen daughters in a primarily rural area. Soc Mar Q 2011; 17: 4-26.

24. Fastrich H, Jean P, Kenney C. Human papillomavirus (HPV) vaccine: the educational and marketing campaigns in Canada, the United States, and Germany. Health, Environment and Education [serial on the Internet] 2008 [cited 2012 Aug]; 1: 74-80. Available from: http://www.electronic-health-journal.com/documents/UG\%20 Fastrich \% 20al\%20formatted.pdf

25. Trim K, Nagji N, Elit L, Roy K. Parental knowledge, attitudes, and behaviours towards human papillomavirus vaccination for their children: a systematic review from 2001 to 2011. Obstet Gynecol Int 2012; 2012: 921236.

26. Wong CA, Saraiya M, Hariri S, Eckert L, Howlett RI, Markowitz LE et al. Approaches to monitoring biological outcomes for HPV vaccination: challenges of early adopter countries. Vaccine 2011; 29: 878-85.

27. Ministry of Health, The Bahamas. Human papillomavirus vacccine coming to The Bahamas. Nassau: ZNS News; 2011 [updated 2011 Nov 29; cited 2012 Aug 17]. Available from: http://www. znsbahamas.com/news.php?ID $=2942$ 